\title{
PENGEMBANGAN MEDIA PEMBELAJARAN BERBASIS AUDIO VISUAL MENGGUNAKAN POWTOON
}

\section{Sofi Maulidah, Lukman Nulhakim, Nana Hendracipta}

Fakultas Keguruan Dan Ilmu Pendidikan Universitas Sultan Ageng Tirtayasa (UNTIRTA) Serang Banten, Indonesia

Email: sofimaulida30@gmail.com, lukman.nulhakim@untirta.ac.id, nanahendracipta@untirta.ac.id

\begin{abstract}
Abstrak
Tujuan dari penelitian ini adalah untuk mengetahui proses pengembangan dan kelayakan media pembelajaran berbasis audio visual menggunakan powtoon dan respon peserta didik setelah belajar menggunakan media pembelajaran berbasis audio visual dengan menggunakan powtoon. Penelitian dan pengembangan atau research and development $(\mathrm{R} \& \mathrm{D})$ untuk menguji kelayakan dari produk tersebut, dilakukan uji validasi. Validasi ahli dilakukan oleh ahli materi dan ahli media dengan subyek penelitian 20 pesesrta didik kelas III SD Negeri Serang 21. Berdasarkan hasil penelitian bahwa media pembelajaran berbasis audio visual dengan menggunakan powtoon dinyatakan "sangat layak" oleh dua ahli media dengan rata-rata persentase $83 \%$ dan dinyatakan "sangat layak" oleh dua ahli materi dengan rata-rata persentase $87 \%$. Respon yang diberikan peserta didik mendapatkan persentase $96,25 \%$ yang termasuk "sangat baik". Dari penelitian, dapat disimpulkan bahwa media pembalajaran berbasis audio visual dengan menggunakan powtoon sangat layak digunakan dalam proses pembelajaran.
\end{abstract}

Kata Kunci: media pembelajaran; powtoon audio-visual; energi; perubahannya

\section{Abstract}

The purpose of this study is to know the development and feasibility process of audio visual-based learning media using powtoon and the response of students after learning to use audio visual-based learning media using powtoon. Research and development $(R \& D)$ to test the feasibility of the product, conducted validation test. Expert validation is done by material experts and media experts with research subjects 20 students of grade III SD Negeri Serang 21. Based on the results of the study that audio visual-based learning media using powtoon was declared "very feasible" by two media experts with an average percentage of $83 \%$ and declared "very feasible" by two material experts with an average percentage of $87 \%$. The response given by the students received a percentage of $96.25 \%$ which included "excellent". From the research, it can be concluded that audio visual-based learning media using powtoon is very feasible to use in the learning process.

Keywords: learning media; audio-visual powtoon; energy and its changes

\begin{tabular}{ll}
\hline How to cite: & Maulidah, Sofi., Lukman Nulhakim, Nana Hendracipta (2021) Pengembangan Media Pembelajaran \\
& Berbasis Audio Visual Menggunakan Powtoon. Syntax Literate: Jurnal Ilmiah Indonesia. 6(7). \\
& http://dx.doi.org/10.36418/ syntax-literate.v6i7.3509 \\
E-ISSN: & 2548-1398 \\
Published by: & Ridwan Institute
\end{tabular}




\section{Pendahuluan}

Kegiatan pembelajaran adalah rangkaian peristiwa (events) yang memengaruhi pembelajaran sehingga proses belajar dapat berlangsung dengan mudah (Rahayu, 2015). Kegiatan pembelajaran ini dilakukan oleh dua orang pelaku, yaitu guru dan peserta didik. Perilaku guru adalah mengajar dan peserta didik adalah belajar. Perilaku belajar merupakan proses interaksi terhadap semua situasi yang ada disekitar individu, belajar dapat dipandang sebagai proses yang diarahkan kepada tujuan dan proses berbuat melalui berbagai pengalaman. Sedangkan, Perilaku mengajar merupakan tindakan penyampaian ilmu pengetahuan. Perilaku belajar dan perilaku mengajar tersebut erat kaitannya dengan bahan pembelajaran yang berupa pengetahuan, nilai-nilai kesusilaan, seni, agama, sikap dan keterampilan.

Untuk mencapai keberhasilan kegiatan pembelajaran, terdapat beberapa komponen yang dapat menunjang, yaitu komponen tujuan, komponen materi, komponen strategi belajar mengajar dan komponen evaluasi. Dalam kegiatan pembelajaran tentu diharapkan sebuah pembaruan dimana guru dituntut untuk memiliki keteladanan serta memiliki kemauan untuk mengembangkan potensi dan kreativitas pesena didik. Proses pembelajaran pada setiap satuan pendidikan dasar dan menengah harus interaktif, inspiratif, menyenangkan, menantang dan memotivasi peserta didik untuk berpartisipasi aktif serta memberikan ruang yang cukup bagi kreativitas dan kemandirian sesuai minat, bakat dan perkembangan fisik serta perkembangan psikologis.

Pentingnya penggunaan media pembelajaran bukan hanya membantu siswa dalam memahami materi pembelajaran (Nurrita, 2018). Penggunaan media juga menyababkan siswa lebih senang dan antusias. Proses mental tersebut sangat membantu membangkitkan motivasi belajar yang pada akhirnya dapat membuat siswa lebih berupaya ketika menemukan berbagai masalah dalam proses pembelajaran. Penggunaan media ini tentu saja membantu guru dalam mentransformasikan pengetahuan kepada siswanya.

Media pembelajaran merupakan segala sesuatu yang digunakan dalam kegiatan pembelajaran agar dapat merangsang pikiran, perasaan, minat dan perhatian siswa sehingga proses interaksi komunikasi edukasi antara guru (atau pembuat media) dan siswa dapat berlangsung secara tepat guna dan berdayaguna (Zaini \& Dewi, 2017). Media pembelajaran memiliki kaitan yang sangat erat, proses pembelajaran tidak akan berjalan lancar tanpa adanya media pembelajaran yang tepat. Media adalah perantara atau pengantar pesan dari pemberi kepada penerima pesan (Wahidin, 2017). Menurut AECT, media adalah segala bentuk dan saluran yang digunakan orang untuk menyalurkan pesan atau informasi. Penggunaan media yang tepat mampu menyampaikan informasi maupun pesan yang disampaikan oleh penyampai pesan dapat diterima dengan jelas oleh penerima pesan. Begitu juga ketika media digunakan dalam proses pembelajaran di kelas, informasi yang disampaikan guru sebagai penyampai pesan di kelas dapat diterima dengan jelas oleh siswa sebagai penerima pesan di kelas (Mahnun, 2012). 
Pemanfaatan media yang baik serta memadai, diharapkan dapat merangsang pikiran, perasaan, perhatian dan minat siswa sehingga proses pembelajaran dapat berjalan dengan baik dan menggairahkan. Verbalisme mungkin saja akan muncul ketika pembelajaran tanpa menggunakan media. Namun, dengan menggunakan media unsur verbalisme dapat dikurangi bahkan dihilangkan. Mengurangi atau menghilangkan unsur verbalisme, maka siswa akan diberikan pengertian dan konsep yang sebenarnya secara realistis dan teliti, serta memberi pengalaman menyeluruh yang pada akhirnya memberi pengertian yang konkret.

Video pembelajaran ini mengacu kepada pembelajaran mandiri yang terdapat pada pembelajaran tematik yang melatih peserta didik untuk mencari sendiri informasi yang mereka butuhkan dan tidak tergantung kepada guru. Hal ini dimaksudkan agar peserta didik tetap belajar mandiri dan secara aktif. Selain memberikan materi konsep IPA yaitu energi dan perubahan, video ini juga menjadikan peserta didik lebih antusias karena video tersebut di desain semenarik mungkin dengan adanya tokoh-tokoh kartun didalamnya. Video tersebut juga terdapat animasi-animasi yang dapat mengunjung video powtoon tersebut agar lebih menarik untuk peserta didik di Sekolah Dasar (Fitriani, 2019). Adanya animasi dan perpaduan warna yang menarik dapat membuat peserta didik menjadi lebih tertarik untuk belajar. Tingkat motivasi belajar peserta didik juga meningkat, selanjutnya akan meningkatkan hasil belajar peserta didik tersebut. Selain itu, video juga memiliki kemampuan menampilkan suatu hal sesuai dengan kondisi, situasi dan tujuan ditampilkan suatu hal sesuai dengan kondisi, situasi dan tujuan ditampilkannya media tersebut yang digambarkan dengan animasi-animasi.

Hasil observasi dan wawancara tidak terstruktur yang dilakukan pada saat pembelajaran di Sekolah Dasar Negeri Serang 21 kelas 3 diperoleh hasil bahwa dalam proses pembelajaran guru hanya mengunakan buku paket. Buku guru dan buku siswa yang diterbitkan oleh Kemendikbud. Selain buku pendamping tersebut, peserta didik juga menggunakan bahan ajar konvesional, yang didalamnya berisikan ringkasan materi atau latihan soal yang tidak jauh dari buku pendamping dan LKS yang biasa digunakan di sekolah-sekolah pada umumnya.

Selain itu, fasilitas yang terdapat di Sekolah Dasar Negeri Serang 21, sudah memiliki fasilitas yang cukup memadai, namun penggunaannya kurang dapat dimaksimalkan oleh guru untuk menyampaikan materi-materi pembelajaran, terutama pada konsep IPA. Padahal, sesuai dengan perkembangan zaman, anak-anak lebih tertarik dengan hal-hal yang berkaitan dengan digital. Fasilitas-fasilitas tersebut seharusnya digunakan untuk alat bantu menyampaikan materi pada saat proses pembelajaran, terutama LCD proyektor. LCD pronyektor ini dapat dimanfaatkan sebagai media.

Pengembangan video pembelajaran yang berbasis Powtoon pada materi energi dan perubahannya menjadi solusi untuk menjawab permasalahan tersebut (Asyifa, 2018). Video termasuk kedalam media pembelajaran jenis multimedia, yang mana didalamnya terdapat gambar dan suara. Bukan hanya dengan gambar dan suara, dalam suatu proses pembelajaran yang menggunakan multimedia, peserta didik belajar tidak 
hanya dari satu jenis media saja, akan tetapi dari berbagai macam media secara bersamaan yang dirancang secara utuh (Sanjaya, 2012). Peserta didik dapat belajar dengan menfaatkan kedua indera sekaligus, yaitu penglihatan dan pendengaran. Dengan demikian, peserta didik mendapatkan pengalaman belajar malalui melihat dan mendengar.

Dari hasil observasi diatas maka peneliti bertujuan untuk mengembangkan video animasi pembelajaran berbasis powtoon untuk digunakan pada pembelajaran materi IPA tentang Energi dan Perubahannya di Sekolah Dasar (SD). Video animasi pembelajaran ini diharapkan bisa dipergunakan sebagai penunjang media pembelajaran di sekolah tersebut. Hal ini disebabkan tersedianya sarana dan prasarana penunjang yang mampu untuk media pembelajaran berbasis audio visual dengan aplikasi Powtoon (Meianti, 2018).

\section{Metode Penelitian}

Metode penelitian yang digunakan Ialah metode penelitian dan pengembangan atau Research and Development (R\&D) yaitu penelitian yang digunakan untuk menghasilkan produk tertentu dan menguji keefektifan produk tersebut supaya dapat berfungsi di masyarakat luas (Sugiyono, 2012). Penelitian dan pengembangan ini akan menghasilkan produk akhir berupa video pembelajaran ilmu pengetahuan alam dengan materi energi dan perubahannya.

Desain penelitian yang akan digunakan dan diterapkan adalah desain penelitian dari Borg and Gall yang terdapat 10 langkah-langkah penelitian dan pengumpulan data, perencanaan, pengembangan draf produk awal, uji awal lapangan, revisi tahap pertama, uji coba lapangan, penyempurnaan produk, uji pelaksanaan lapangan, penyempurnaan produk akhir, serta desimasi dan implementasi.

Pengumpulan data di sini berupa studi literatur dan angket. Studi literalur, angket dan dokumentasi. Studi literature digunakan untuk merencanakan pengembangan suatu produk sehingga dapat menghasilkan media video pembelajaran yang dapat dimanfaatkan oleh guru dan peserta didik. Data yang dikumpulkan berupa studi literatur analisis kurikulum dan analisis materi pelajaran. Angket digunakan untuk analisis kebutuhan pada materi energi dan perubahannya. Dokumentasi digunakan untuk memperkuat data yang diperoleh dan juga untuk memperoleh data langsung dari tempat penelitian, laporan kegiatan, foto-foto dan data penelitian yang relavan (Riduwan \& Kuncoro, 2012).

Data yang diperoleh melalui instrument penilaian pada saat uji coba dan dianalisis dengan menggunakan deskriptif kualitatif. Analisi ini dimaksud untuk menggambarkan karakteristik data pada masing-masing variable.

\section{Hasil dan Pembahasan}

Penelitian dan pengembangan ini bertujuan untuk menghasilkan media pembelajaran berbasis audio visual dengan menggunakan powtoon dengan materi energi 
dan perubahannya pada kelas III Sekolah Dasar semester II. Kegiatan penelitian ini di1akukan dari tanggal 21 Februari sampai dengan 25 Februari 2020.

Dari hasil angket yang telah diisi oleh guru, dapat dilihat bahwa kurikulum yang sekolah mereka gunakan ialah Kurikulum 2013. Guru mayoritas menggunakan buku yang diberikan oleh dinas dan membeli buku tambahan lain seperti LKS dan buku paket dari penerbit lain. Mereka juga jarang menggunakan video dalam proses pembelajaran IPA, khususnya pada materi energi dan perubahan. Sehingga responden yaitu guru setuju dengan adanya pembuatan media pembelajaran berbentuk video tersebut.

Pengembangan produk yang dikembangkan adalah berupa media pembelajaran berbasis audio visual dengan menggunakan powtoon yang diperuntukan untuk kelas III Sekolah Dasar pada mata pelajaran IPA semester II (Hendawati, Putri, Pratomo, \& Widianingsih, 2018). Tahap-tahap dalam pembuatan media pembelajaran berbasis audio visual dengan menggunakan powtoon antara lain (Buchori \& Cintang, 2018):

1. Membuat rancangan garis besar atau biasa disebut story board. Pembuatan story board ini bertujuan untuk membuat rancangan awal agar mempermudah peneliti untuk menyusun bagian demi bagian media pembelajaran berbasis audio visual dengan menggunakan powtoon tersebut.

2. Penentuan tema bertujuan untuk mendapatkan konsistensi dalam pembuatan media pembelajaran berbasis audio visual dengan menggunakan powtoon tersebut.

3. Pada tahap pembuatan, peneliti mengumpulkan bahan-bahan yang digunakan sebagai pendukung dalam membuat media pembelajaran berbasis audio visual dengan menggunakan powtoon tersebut.

4. Validasi uji ahli, sebelum produk hasil pembuatan diuji cobakan, produk yang telah dikembangkan tersebut harus melewati tahap validasi (uji ahli) terlebih dahulu dengan tujuan untuk mengetahui apakah media berbasis audio visual dengan menggunakan powtoon ini telah memenuhi kriteria atau belum.

5. Hasil Validasi;

a. Validasi Ahli Media dilihat dari empat aspek utama, yaitu aspek tampilan, desain video, penggunaan, pemanfaatan.

\section{Tabel 1}

\section{Data Penilaian Validasi Ahli Media}

\begin{tabular}{ccc}
\hline Validator & $\begin{array}{c}\text { Persentase } \\
(\boldsymbol{\%})\end{array}$ & Keterangan \\
\hline I & $79 \%$ & Layak \\
\hline II & $86 \%$ & Sangat Layak \\
\hline
\end{tabular}

b. Validasi Ahli Materi dilihat dari tiga aspek utama yaitu, aspek kelayakan isi, aspek kelayakan penyajian, dan yang terakhir yaitu aspek bahasa. 


\section{Tabel 2}

Data Penilaian Validasi Ahli Materi

\begin{tabular}{ccc}
\hline Validator & $\begin{array}{c}\text { Persentase } \\
(\mathbf{\%})\end{array}$ & Keterangan \\
\hline I & $91 \%$ & Sangat Layak \\
\hline II & $83 \%$ & Sangat Layak \\
\hline
\end{tabular}

6. Uji Coba Produk; dilakukan setelah media pembelajaran direvisi oleh peneliti atas dasar saran dari validator dan sudah mendapatkan sangat layak untuk digunakan.

Tabel 3

Data Hasil Respon Peserta Didik

\begin{tabular}{ccccc}
\hline \multirow{2}{*}{ KET } & \multicolumn{4}{c}{ ASPEK } \\
\cline { 2 - 5 } & IM & B & $\mathbf{P}$ & K \\
\hline $\begin{array}{c}\text { Total } \\
\text { Skor }\end{array}$ & 195 & 38 & 117 & 40 \\
\hline$\%$ & 97,5 & 95 & 92,5 & 100 \\
\hline KET & $\begin{array}{c}\text { Sangat } \\
\text { Baik }\end{array}$ & $\begin{array}{c}\text { Sangat } \\
\text { Baik }\end{array}$ & $\begin{array}{c}\text { Sangat } \\
\text { Baik }\end{array}$ & $\begin{array}{c}\text { Sangat } \\
\text { Baik }\end{array}$ \\
\hline
\end{tabular}

Keterangan: IM = Isi / Materi, $\mathrm{B}=$ Bahasa, $\mathrm{P}=$ Penyajian, $\mathrm{K}=$ Kegrafikan

Berdasarkan hasil penelitian yang telah dilaksanakan mengenai pengembangan media pembelajaran berbasis audio visual dengan menggunakan powtoon pada mata pelajaran IPA materi energi dan perubahannya kelas 3 (Pramowardhani, 2020). Diketahui bahwa berkurangnya motivasi para siswa untuk belajar atau beradaptasi di dalam belajar, kurangnya sekolah menentukan guru yang kompetif didalam melakukan pembelajaran atau terlalu monoton dalam proses pembelajaran di sekolah, kurangnya guru dalam melakukan sebuah hubungan atau relasi dengan para siswa yang menjadi peserta didiknya, kurangnya maksimal didalam penggunaan alat atau media pembelajaran yang menjadi pendukung di dalam aktivitas belajar mengajar. Sehingga dibutuhkan pelatihan dalam pembuatan alat atau media pembelajaran, sehingga peserta tidak merasakan jenuh dalam proses pembelajaran. Selain itu, dibutuhkan kerja sama yang baik antara pendidik dengan kepala sekolah dan siswa. Pengunaan media pada proses pembelajaran akan lebih meningkatkan hasil belajar dibandingkan tidak menggunakan media (Wati, 2014).

Pengembangan media pembelajaran berbasis audio visual dengan menggunakan powtoon ini dikemas dengan desain yang menarik untuk peserta didik. Pemilihan warna dan desain background disesuaikan dengan perkembangan peserta didik. Bukan hanya warna desain, peneliti juga memperhatikan pemilihan jenis huruf dan warna yang akan digunakan. Media pembelajaran ini juga terdapat kegiatan atau aktivitas-aktivitas peserta didik seperti mengamati, menanya, mengumpulkan informasi, berdiskusi dan menyampaikan kembali apa yang didapatkan dari hasil diskusi bersama teman kelompoknya. Proses pembelajaran ini berdasarkan kurikulum yang digunakan oleh sekolah yaitu Kurikulum 2013 yang dominan stundent center dimana proses belajar di dominasi oleh peserta didik itu sendiri. 
Media pembelajaran berbasis audio visual dengan menggunakan powtoon ini menggunakan bahasa yang sesuai dengan tingkat perkembangan peserta didik. Kalimat yang digunakan dalam video pembelajaran sederhana, komunikatif, struktur dan interaktif (Sanjaya, 2012). Bahasa adalah pokok utama dalam menyampaikan pesan, agar pesan atau informasi dapat tersampaikan dengan baik peneliti memilih bahasa yang sesuai dan tidak merubah konsep dari materi itu sendiri.

Dilihat dari kebutuhan peserta didik pada masa penelitian. Peneliti membuat pengembangan media berbasis audio visual dengan menggunakan powtoon ini pada materi energi dan perubahannya. Dimana dalam proses pembelajaran peserta didik diajak untuk lebih aktif dalam mengumpulkan informasi sesuai dengan manfaat video pembelajaran pada umumnya.

Ketercapaian atau kelayakan media pembelajaran berbasis audio visual dengan menggunakan powtoon ini dibuktikan melalui validasi dari ahli media dan ahli materi dengan hasil berikut: validator ahli media I memberikan nilai dengan persentase $79 \%$, dan validator ahli media II memberikan nilai dengan persentase $86 \%$. Dilihat dari nilai yang diberikan, validator ahli media I memberikan nilai $79 \%$ dengan hasil catatan yaitu terdapat beberapa revisi, seperti identitas peneliti harus memakai foto, SK dan KD diganti dengan tujuan pembelajaran, tulisan tidak boleh berrwarna merah, dan suara kurang jelas. Sedangkan, validator pada ahli materi I memberikan nilai persentase $91 \%$, dan validator ahli materi II memberikan nilai persentase $83 \%$. Dilihat dari nilai yang diberikan, validator ahli materi I memberikan nilai 91\% dengan hasil catatan yaitu terdapat beberapa revisi terdapat pada perubahan energi kimia menjadi energi listrik contohnya aki.

Penjelasan berikut menunjukan bahwa media pembelajaran berbasis audio visual dengan menggunakan powtoon untuk peserta didik di sekolah dasar sudah baik menurut ahli media dan ahli materi yang di dalam ahli materi sudah terdapat penilaian tentang aspek bahasa.

Selanjutnya, peneliti memberikan angket kepada peserta didik terkait media pembelajaran berbasis audio visual dengan menggunakan powtoon yang telah digunakan. Didapatkan hasil respon dari peserta didik yaitu dengan nilai persentase 97,5\% pada aspek isi atau materi, 95\% pada aspek bahasa, 92,5\% pada aspek penyajian dan $100 \%$ pada aspek kegrafikan. Hal tersebut didapatkan karena peserta didik merespon dengan baik media pembelajaran berbasis audio visual dengan menggunakan powtoon tersebut. Pada aspek materi terdapat 5 peserta didik yang menjawab isi dan materi yang terdapat dalam media berbasis audio visual dengan menggunakan powtoon tidak dapat dipahami dan sesuai, Aspek Bahasa terdapat 2 peserta didik berpendapat bahwa Bahasa yang digunakan kurang mudah dimengerti. Selain itu dilihat pada aspek penyajian terdapat 3 peserta didik yang berpendapat bahwa gambar dan animasi yang terdapat dalam media kurang menarik. Sedangkan, jika dilihat dari aspek kegrafikan terdapat 20 peserta didik yang menyatakan jenis huruf dan ukuran pada media terbaca dengan baik. Jadi, dapat disimpukan bahwa hasil respon peserta didik mendapat nilai persentase 96,25\% dan termasuk dalam kategori sangat baik. Dapat ditarik kesimpulan 
bahwa peserta didik memiliki ketertarikan yang tinggi terhadap media pembelajaran berbasis audio visual dengan menggunakan powtoon tersebut.

\section{Kesimpulan}

Pengembangan media pembelajaran berbasis audio visual dengan menggunakan powtoon pada materi energi dan perubahaannya kelas 3 ini dilakukan berdasarkan prosedur pengembangan yang dikemukakan oleh Borg and Gall yang telah dikembangkan kembali oleh Sugiyono. Proses pengembangan melalui 6 tahapan yaitu: a) Analisis Masalah, b) Mengumpulkan Informasi, c) Desain Produk, d) Validasi Desain, e) Revisi Produk dan f) Uji Coba Produk. Uji coba dilakukan kepada 20 pesena didik kelas III di SD Negeri Serang 21. Sekolah yang digunakan adalah sekolah yang sudah menggunakan Kurikulum 2013.

Kelayakan media pembelajaran berbasis audio visual dengan menggunakan powtoon pada materi Energi dan Perubahaannya kelas 3 didapatkan hasil penilaian penilaian ahli media dan ahli materi. Hasil penilaian dari ahli media, memperoleh persentase nilai akhir $83 \%$ yang temasuk kedalam kategori "sangat layak". Hasil penilaian dari ahli materi, memperoleh persentase nilai akhir $87 \%$ yang termasuk kedalam kategori "sangat layak".

Respon peserta didik terkait media pembelajaran berbasis audio visual dengan menggunakan powtoon ini dapat dilihat dari hasil penyebaran angket yang dilakukan oleh peneliti. Hasil yang diperoleh yaitu dengan persentase $96,2 \%$ yang termasuk dalam kategori "sangat baik". Rata-rata persentase tersebut dilihat dari aspek isi atau materi sebesar 97,5\%, aspek Bahasa 95\%, aspek penyajian 92,5\% dan aspek kegrafikan sebesar $100 \%$. 


\section{BIBLIOGRAFI}

Asyifa, S. M. (2018). Pengembangan Video Pembelajaran untuk Mengembangkan Kemampuan Pemahaman Konsep Matematis di Sekolah Dasar. Jurnal Ilmiah, 1-7. Google Scholar

Buchori, Achmad, \& Cintang, Nyai. (2018). The Influence of Powtoon-Assisted Group to Group Exchange and Powtoon-Assisted Talking Chips Learning Models in Primary Schools. International Journal of Evaluation and Research in Education, 7(3), 221-228. Google Scholar

Fitriani, Nina. (2019). Pengembangan Media Pembelajaran Audio-Visual Powtoon Tentang Konsep Diri Dalam Bimbingan Kelompok Untuk Peserta Didik Sekolah Dasar. Jurnal Tunas Bangsa, 6(1), 104-114. Google Scholar

Hendawati, Yuyu, Putri, Suci Utami, Pratomo, Suko, \& Widianingsih, Fitri. (2018). Penerapan Model Mind Mapping Untuk Meningkatkan Penguasaan Konsep IPA di Sekolah Dasar. Metodik Didaktik, 13(2), 113-124. Google Scholar

Mahnun, Nunu. (2012). Media pembelajaran (kajian terhadap langkah-langkah pemilihan media dan implementasinya dalam pembelajaran). An-Nida', 37(1), 2734. Google Scholar

Meianti, Andis. (2018). Pengembangan Media Pembelajaran Berbasis Audio Visual Powtoon pada Kompetensi Dasar Menerapkan Promosi Produk Kelas X Pemasaran SMK Negeri Mojoagung. Jurnal Pendidikan Tata Niaga (JPTN), 6(2). Google Scholar

Nurrita, Teni. (2018). Pengembangan media pembelajaran untuk meningkatkan hasil belajar siswa. Misykat: Jurnal Ilmu-Ilmu Al-Quran, Hadist, Syari'ah Dan Tarbiyah, 3(1), 171-210. Google Scholar

Pramowardhani, Anggi. (2020). Pengaruh Model Guided Discovery Learning Berbasis Media Audiovisual Terhadap Hasil Belajar IPA. Syntax Literate; Jurnal Ilmiah Indonesia, 5(7), 240-250. Google Scholar

Rahayu, Entin Fuji. (2015). Manajemen Pembelajaran dalam Rangka Pengembangan Kecerdasan Majemuk Peserta Didik. Manajemen Pendidikan, 24(5), 357-366. Google Scholar

Riduwan, Engkos Achmad Kuncoro, \& Kuncoro, Achmad. (2012). Cara menggunakan dan memaknai path analysis (analisis jalur). Bandung: Alfabeta.

Sanjaya, Wina. (2012). Media komunikasi pembelajaran. Jakarta: Kencana Prenada Media Group. Google Scholar

Sugiyono, P. D. (2012). Metode Penelitian Kuantitatif Kualitatif Dan R\&D (Vol. 8). 
Pengembangan Media Pembelajaran Berbasis Audio Visual dengan Menggunakan Powtoon

Alfabeta. Bandung.

Wahidin, Unang. (2017). Interaksi Komunikasi Berbasis Media Pembelajaran dalam Proses Belajar-Mengajar. Edukasi Islami: Jurnal Pendidikan Islam, 4(07), 197. Google Scholar

Wati, E. K. A. Hajar. (2014). Pengembangan Media Video Boneka Tangan dalam Pembelajaran Harga Diri Mata Pelajaran Pendidikan Kewarganegaraan Siswa Kelas 3 SDN Sumberejo 2 Pakal Surabaya. Jurnal Mahasiswa Teknologi Pendidikan, 5(2). Google Scholar

Zaini, Herman, \& Dewi, Kurnia. (2017). Pentingnya media pembelajaran untuk anak usia dini. Raudhatul Athfal: Jurnal Pendidikan Islam Anak Usia Dini, 1(1), 81-96. Google Scholar

\section{Copyright holder:}

Sofi Maulidah, Lukman Nulhakim, Nana Hendracipta (2021)

\section{First publication right:}

Syntax Literate: Jurnal Ilmiah Indonesia

This article is licensed under:

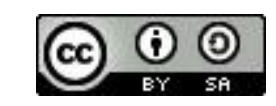

